\title{
Strategy of Strengthening Corruption Prevention and Enforcement through Social Punishment: A Sociological Study
}

\author{
${ }^{1}$ Zainuddin Syarif, ${ }^{2}$ Abd Hannan, ${ }^{3}$ Ali Hamzah, ${ }^{4}$ Yasni Efyanti \\ 1,2, IAIN Madura, Pamekasan, Indonesia \\ ${ }^{3,4}$ IAIN Kerinci, Jambi, Indonesia
}

Article Info

Volume 83

Page Number: 12180 - 12192

Publication Issue:

March - April 2020

\section{Article History}

Article Received: 24 July 2019

Revised: 12 September 2019

Accepted: 15 February 2020

Publication: 17 April 2020

\begin{abstract}
:
Corruption is an extraordinary crime that can threaten the survival of many people's lives. Therefore, the existence of corruption must be prevented and eradicated at its roots. Corruption occurs through complex factors, not only caused by structural but also cultural factors. Therefore, the eradication of corruption is not enough in the structural measures such as punishment, but need to extendto other penalties such as social sanction. This study is a descriptive qualitative study with library techniques. The theoretical perspective used in this study is the theory of sociology of corruption; social control theory. In general, the findings of this study include an explanation of the dynamics of corruption in Indonesia, as well as the role and strategic function of social punishment for eradicating corruption in Indonesia. Sociologically, the role and strategic function of social punishment in an effort to maximize the eradication of corruption can be done by building synergy between all social structures of society. The social structure in question is the family, tradition, law enforcement, education, and religious institutions.
\end{abstract}

Keywords: Prevention, Enforcement, Corruption, Social Punishment.

\section{INTRODUCTION}

Genealogically, the history of corruption in Indonesia has a long historical setting. Corruption has taken root for a long time, long before Indonesia found its status as a sovereign state (read: independent). In the kingdom period, the practice of corruption can be traced to the rise of the practice of venality of power.[1]. In this era, corrupt behavior is carried out through transactional activities, buying and selling, and bribery of positions at the level of the royal structure, both from the top and underlying level. In this section, we can conclude that those who have strong financial capabilities, have broad power relations, and have large social capital, have a great opportunity to gain a position, to control the natural resources in their environment.[2].

In the next period, corruption behavior in Indonesia can also be traced when Indonesia is under the authority of the colonial state. At this time, corruption occurs due to arbitrary use of power.[3]. The sole authority possessed by the colonialists and the absence of a controlling body that oversees the running of power, in the end made power run wild. In the period, corruption occurred in the form of an 


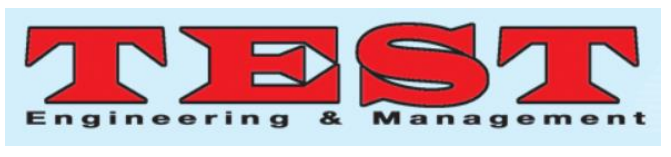

arbitrary system of government, the use of power and positions tended to be abused and misused.[4]. Power is not intended to the welfare of the people, but rather only for personal interests and certain groups.

The problem of Indonesia's corruption continues until the time when the country began to enter independence. In the era of Soekarno's leadership, corruption became a thing that frightening when he was appointed as president for life through the decision of MPRS (the People's Consultative Assembly of the Republic of Indonesia) Number III/MPRS/1963.[5]. This decision raises suspicion and concern from many groups, because it has the potential to cause abuse of authority. In the new order era, corruption seemed to find its momentum along with the existence of a centralistic governmental pattern adopted by the Soeharto leadership regime.[6]. During the period 1967-1998 corruption grow rapidly, bringing the country to the brink of a deep crisis. Quoting from Lord Acton words (1834-1902), power tends to be corrupt, and absolute power is corrupt absolutely.[7]. And even today, after going through a long period of leadership, from Sukarno to the leadership of President Jokowi, corruption is still a frightening specter.[8]. It is marked by the high index of our perspective of corruption, even we are still inferior to neighboring countries, such as Malaysia and Singapore.

Table 1 Indonesia's Corruption Perception Index (CPI) in the Last Decade

\begin{tabular}{|c|c|c|}
\hline Years & CPI Scores & Ratings \\
\hline 2009 & 28 & 111 \\
\hline 2010 & 28 & 110 \\
\hline 2011 & 30 & 100 \\
\hline 2012 & 32 & 118 \\
\hline 2013 & 32 & 114 \\
\hline 2014 & 34 & 107 \\
\hline 2015 & 36 & 88 \\
\hline 2016 & 37 & 90 \\
\hline 2017 & 37 & 96 \\
\hline 2018 & 38 & 89 \\
\hline
\end{tabular}

Source: Indonesian International Transparency, 2019
The high number of perception index in Indonesia suggests that the process of handling corruption in Indonesia still leaves many problems and need a massive work.[9]. In fact, since the reformation began, the agenda for eradicating corruption has strengthened, both institutionally and legally. he establishment of the Corruption Eradication Commission (KPK), as well as the application of articles of corruption in the legal system.[10]. Ideally, the enactment of punishment should have a deterrent effect, so the chances of a repeat of similar crimes in the future can be reduced. The application of criminal threats in the PTPK Law is to provide a deterrent effect on corruptors and prevent the potential for corruption that has currently developed elitist, endemic, and systemic.[11]. Unfortunately, the granting of a deterrent effect in the context of enforcing corruption is still limited to imprisonment, fines and additional crimes as stipulated in Law No. 31/1999 as well as Law No. 20/2001 on Eradicating Corruption. In reality, action through these instruments has not been proven to transmit the deterrent effect.[12], so that the eradication of corruption is far from the fire.

In this regard, Asnawi (2013) explains that the application of positive legalistic law in Indonesiaincluding in the context of corruption measures still leaves a blank space which has an effect on infertility legalissues.[13]. Infertility arises as a result of building a legal positivism paradigm that does not stand on a (should) comprehensive perspective. Worse, the condition is exacerbated by the number of cases of judges' decisions which are relatively mild.[14]. These problems then demanded the need for new breakthroughs to formulate other more effective action formulations. Not only oriented to imprisonment, but also helped foster mental drive so not to appearthe same violations of the lawnot to appear in the future. One of the mental impulses meant is through the imposition of social sanctions.[15]. 
Social sanctions, as an additional law, can also be used as indicators of the strength of community understanding and support. Increasing public participation as government partners in the agenda of preventing and controlling corruption.[16]. It can be used as a step to optimize the eradication of corruption; it will be very strategic if the idea of social punishment is included in the strategy of preventing and fighting corruption. The prosecution of corrupt convicts through imprisonment and social punishment will be a combination of sentences that complement and reinforcing.[17].

This thinking framework, this study has a special interest, namely conducting a sociological study of the prevention and enforcement of corruption through the application of social punishment. Several themes related to corruption, prevention and prosecution, social sanctions, all of which will be the focus of the study that will be discussed in this study.

\section{METHOD}

This study is a qualitative study using the literature method. The method of literature or well-known as literature study is a method that emphasizes the use of literature as the main data source. The term literature refers to any scientific study that has relevance to the focus of the issues raised in this paper.[18]. On this occasion, data tracking through literature study focused on two major themes; the concept of corruption and the concept of social sanctions. In order to obtain objective data, the literature study in this study emphasizes the reading of new data, particularly those sourced from research results, both in the form of theses, theses, dissertations, and research journals.

In the data analysis process, this study uses Miles and Haberman (1984) data analysis techniques. In the Miles and Haberman method, there are three stages of data analysis.[19], namely; First, data reduction. This stage is a summarizing activity, determining the most important topics, focusing attention on the main points of research by looking for forms or patterns. In this study, data reduction is done by selecting and grouping data based on the research issues raised in this study. the research problem in question is the prevention and enforcement of corruption and social punishment. Second, data presentation. Data presentation is the process of describing data in the form of narration or in-depth description that can describe information or data obtained during observation or information search. Third, the final stage of data analysis is drawing conclusions. The conclusions in this research study contain new findings that have never before existed, namely regarding the significance of the addition or application of social punishment in efforts to strengthen the prevention and enforcement of corruption in Indonesia.

Theoretically, this study uses the approach of the sociology of law, especially the theory of deviant behavior and the theory of social sanctions. There are three (3) main reasons for the importance of raising the problem of corruption from the perspective of legal sociology. First, corruption is related to social systems and structures, in this case the structure of society. Thus, it becomes impossible then to separate corruption from people's lives and all its social aspects; covering tradition, culture, and various values that apply in it. Second, sociology is a social scientific discipline that has the advantage of seeing complex social problems, not merely from a single point of view (normative law), but more than that involves aspects (social). Third, sociology has relevance to the ideals of the realization of a stable society (social stability). For example, sociology assesses corrupt behavior as a form of deviant behavior that can disrupt social stability, threaten the social integration of society. Based on some of the above advantages, this study has an interest in terms of conducting in-depth sociological studies, regarding enforcement and prevention of corruption through the application of social penalties. 


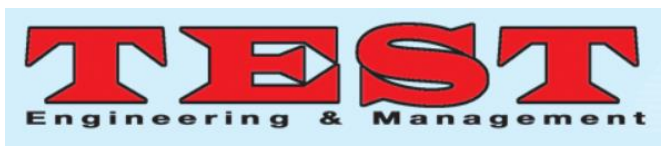

\section{RESULT AND DISCUSSION}

\section{Conceptual Framework of Corruption}

Historically, the use of the term corruption turned out to have a dual function, namely positive functions and negative functions. In its time, the positive function of corruption was aimed at improving the economy. Especially in the economic sector activities in the 1970s and early 1980s. During this period, corruption was seen by corruption apologists as a lubricant for the economic system that was not working efficiently due to the malfunctioning of the bureaucracy and overlapping regulations in the government sector. In this view, the practice of corruption is considered as an incentive for public employees to serve their clients best. In a sense, corruption will be truly beneficial when the bureaucracy is really not functioning so it needs lubricant.[20]. As for corruption as a negative behavior, it literally comes from the Latin corruptia or corroptus, which means that is decay, badness, depravity, dishonesty, can be bribed, and immoral.[21]. Understanding corruption literally implies bad behavior, destructive, and far from the nature of humanism.

According to the World Bank and UNDP, corruption is defined as the abuse of public office for private gain.[22]. In a broader sense, corruption is the misuse of public power for personal or private interests which harms the public in ways contrary to applicable legal provisions. Haryatmoko (2011) defines corruption as an effort to use the ability to intervene because of its position to misuse information, decisions, influence, money or wealth for its interests and benefits.[23]. Rose Ackerman (1999) defines corruption as illegal payments to public officials for profit.[24]. Meanwhile, according to Johnston and Heidenheimer (2009), corruption is an abuse of the roles and resources of the public or the use of unauthorized forms of political influence, which are carried out by public or private parties.[25].

As a form of major crime, corruption is carried out in various modes and forms. Opportunities for corruption in the social system sector do not stand alone, but involve intellectual actors, utilizing the positions and strategic authority they occupy. Wijayanto and Ridwan Zachrie (2010) in a book titled 'Korupsi Mengorupsi Indonesia; Sebab Akibat dan Prospek Pemberantasan' interestingly illustrates the areas and opportunities where corruption is often operated. There are at least three areas where corrupt practices take place, namely:

\section{Desires and Opportunities}

One factor that trigger corrupt behavior is the encouragement of an individual mentality that originates from desires and opportunities. Corrupt behavior that is driven by desires and opportunities often occurs at the same time. The difference is, the desire to behave in a corrupt manner working in the psychiatric realm, is generally influenced by internal psychological drives. Sigmund Frued's psychoanalyst thesis (1856-1939) that humans are individuals who are always driven by desires (homo volens) can be justified.[26].

In addition to the element of desire, opportunity is the second factor that can stimulate the growth of corrupt behavior. The opportunity element is in the range of external factors, particularly with regard to regulation. The weaker and lesser the existence of regulations, the greater the potential for corruption to emerge. Thus, the social system was created as an effort to narrow the space for corruption. The administration, values, and social norms of a society are like system of technology. It must be patterned, structured, systemic and neatly organized, so that there is no space for corruption practices.

\section{Monopoly}

Based on the oxford dictionary, monopoly has meaningmonopoly in/of/on something the complete control, possession, or use of something; a thing that belongs only to one person or group and that other people cannot share. People who are monopolistic means doing control (economically) alone.[27]. If based on this understanding, the term monopoly is more likely to be used in economic 
activity. In the context of corruption, monopolistic practices are one of the sources of corrupt behavior. When the sources of commodities are under the control of a group, the chances of impure practices will be higher. The monopoly of power is often followed by corrupt practices. Whether in the form of service, reducing the amount, or reduce the quality.

\section{Value}

In the context of corrupt behavior, values are often reduced to living traditions that are biased materialism and familism. The views of both contain the meaning of hedonism and kinship. In many social relations, both materialism and familism can be a gap in the abuse of power. Corruption can occur due to a hedonic mentality of self. Corruption can also occur when policies or regulations are not rigid because they come into contact with family or kinship ties. The system of government that is built based on the concept of familism is the forerunner to the birth of a dynastic or feudalism government structure. The kinship system in the bureaucratic style is the gateway for the phenomenon of collutive, corrupt and nepotive bureaucracy.[28]. Whereas materialism has strong implications for the embodiment of hedonic and pragmatic mentality. The materialismconcept as introduced by Ludwig Feurbach (1804-1872), and later developed by his student, Karl Marx (181818883) implied worship of matter as the basis of all life. Lipset and Lenz (1999) state that people who exaggerate the material, but do not provide equal opportunities to other groups of people to access economic resources in their environment tend to have high levels of corruption.

\section{Corruption Eradication Strategy}

Based on the law, Law 30/2002 states that the eradication of corruption is a series of actions to prevent and eradicate corruption through sharing efforts; coordination, supervision, monitoring, investigations, prosecutions, and hearings in court hearings with community participation.[29]. Things that need to be emphasized here, in addition to strengthening the enforcement of positive law centered on judicial institutions, the process of eradicating corruption must also include public participation. The presence of the community can be an instrument or approach to give a social deterrent effect on the perpetrators.

During this time the handling of corruption carried out with various approaches. There are many theories and approaches in the corruption eradication agenda. Each theory and approach has advantages and disadvantages of each, thus because each country has a different typology, social culture, and government system, so the perspectives and approaches adopted cannot be compared. For example, the model of eradicating corruption in terms of repression between Middle Eastern countries and other Asian countries, for example Indonesia. Likewise so on.

According to Wijayanto and Ridwan Zechrie (2010), the world corruption approach model can be classified into four. First, lawyer approache. It isan approach that focuses on strengthening law enforcement actions, as well as making regulations and governance systems that are rigid and strict. Leaving no gaps or spaces for corruption, nepotism, and collusion practices.[30]. In Indonesia, this approach has long been applied. Even institutionally, in addition to the existence of the KPK institution, the lawyer approach has been further strengthened by the presence of criminal investigations in police institutions. Second, businessman approach, this instrument is based on the fact that humans are rational creature. The human rationality side pushes itself to take a logical attitude and decision, prioritizing personal considerations based on whether or not their interests and goals are achieved.[31]. With this view, the stability of the system and social structure can be realized by the availability of facilities and motivation, both in the form of material, promotion, and other living needs. Besides being able to function as a reinforcement of bureaucratic systems and structures, providing sufficient incentives will 
easily stimulate a high work ethic, increasing work productivity in the organization. In Indonesia, several regions have implemented this instrument, such as the city government of Surabaya and Jakarta. These two regions provide large salaries to their regional apparatus.

Third, market or economics approach, this approach has a different side with the two previous approaches. If the attorney's approach and the entrepreneur's approach are realized through social relations between agents and clients, government and society, then it is different from the market or economic approach. The economic market approach focuses on the intensity of social interaction of each of the two. Interaction between agents, interactions between clients, and so on and so forth.[32]. By emphasizing social relations within each party will trigger competition. Competition will encourage the birth of creativity, work, and ideas. This approach believes that corrupt behavior is formed due to the lack of individual creativity to establish communication and competition with their environment. These weaknesses then encourage individuals to choose shortcuts, so that it raises evil behavior that is contrary to legislation, corruption and so on.

Fourth, the cultural approach, Edward B. Taylor (1832-1917) in Koenjataraningrat (1987) defines culture as a complex whole thing, in which there is a set of knowledge, beliefs, arts, morals, customary law and all other abilities and habits obtained by humans as a member of society.[33]. In the context of eradicating corruption, the cultural approach entails efforts to instill the values of nobility and virtue. A believe to always be honest in every moment. The workings of eradicating corruption through the cultural sector are very different from other approaches. Do not have a standard method, only need self-creativity how to convey anticorruption messages to the public in an effective way. In a broader perspective, the eradication and prevention of corruption through cultural instruments can be a gateway where the community can be involved. The cultural perspective here requires the presence of the community along with a variety of values and structures in it, such as traditional leaders, religious leaders, cultural leaders, and society as a whole.

\section{Corruption Eradication through Social Sanctions; A Theoretical Analysis}

Before further discussing the eradication of corruption through the application of social penalties or social sanctions, it is important to first know how corruption is placed in the lens of the sociology of corruption. This is important to offer a comprehensive understanding, because the term social sanction itself is a derivative concept adopted from the scientific constructs of sociology, especially those in contact with the themes of community behavior that fall into the category of deviations. In this regard, social sanctions are a sociological reference to resolve various social phenomena in the community known to have social syndromes in the form of deviant behavior. Thus, what exactly meant by deviant behavior here, in relation to the eradication of corruption through social sanctions.

In general definition, deviant behavior is a form of behavior or action that is not in accordance with the norms that exist in society. Emile Durkheim in SoerjonoSoekanto refers to deviant behavior as a type of crime if actions violate norms or regulations in society. When referring to these two definitions, we cannot call corruption normal behavior. It is absolute to say that corruption is a deviant behavior, because it actually contains opposition to the law.[34]. Not only that, corruption also characterizes moral values and humanity, which can bring crucial problems for the survival of the lives of many people. Referring to the explanation of Talcot Parson (2010), the community is an intact structural building consisting of many specific substructures. Each sub structure in it has its own role and function.[35]. Therefore, for society to be stable and balanced, every form of deviation must be suppressed as much as possible. In this context, 
corrupt behavior is a form of deviation, its existence holds the potential for great chaos not only to eradicate the country's wealth, but also to the survival of the lives of many people (read: the people).

Theoretically, deviant behavior is divided into three; 1) Individual deviations, i.e. deviations committed by themselves without any interference from others; 2) Group deviations, a type of deviant behavior that is done together in a particular group. When linked to the dynamics of corruption in Indonesia, corruption is popular with corruption in congregation, as is rife lately. A clear example of group (group) corruption or congregation here is a corruption case in Malang involving 44 members of the local DPRD, or a case of irregularity (corruption) that dragged a number of regional council members. In terms of handling, deviations in the form of groups have a more difficult settlement rate than individuals. It is because it operates collectively and involves many actors; 3 ) Deviations committed by a group or social organization. this form of deviation has different characteristics from social groups. If social groups are only based on elements of involvement, then deviations in this form are also followed by structural ties. Concretely irregularities (corruption) in this sector occur more due to compliance or submission to certain group norms, where these norms at the same time ignore the provisions that apply formally in the community and are legitimate.[36].

In addition, based on its nature, deviant behavior can be grouped into two, namely deviations are positive and deviations are negative. A deviant behavior can be categorized positively when it can present positive effects, both for themselves and the environment. In addition, this form of deviant behavior does not contain elements of conflict with the social system. Another characteristic of this behavior is the existence of innovative and creative elements that can add and enrich people's insights in their environment. The negative deviant behavior refers to the overall behavior that is generally contrary to the values and social norms prevailing in certain societies. This behavior has special criteria, which can trigger the birth of bad things, both for themselves and people in their environment.[37]. Because of its bad nature, negative deviant behavior is classified as behavior that is contrary to the consensus value of the community, so that its existence is always faced with criticism, ridicule, even alienation from social life.

In sociology, the discussion of deviant behavior is identical with social sanctions. If deviant behavior implies syndrome in the presence of social pathology, then social sanctions are means, methods, or instruments of control. Social sanctions are the application of social law whose application involves the direct role of the community. Thus, the deterrent effect is no longer based on the single effect of fear and pain, but also shame and moral burden. If positive law focuses more on the physicalist aspect, then social sanctions are more on psychological pressure and mentality.

If positive law focuses more on the physicalist aspect, then social sanctions are more on psychological pressure and mentality. As such, what exactly is meant by social sanctions? In the Indonesian Dictionary, sanctions refer to nouns, their meanings; ratification, confirmation, dependents (punitive measures and so on) to force people to keep agreements or comply with the statutes of the association's articles of association and so on; acts as punishment to a country; negative rewards in the form of deliverance or suffering determined through law.[38]. When viewed from normative law, social sanctions are generally referred to as social penalties that are applied in the form of social work.[39]. There are various kinds of social work in the process of implementing social crime. For example, such as cleaning public toilets, cleaning ditches or gutters, sweeping the streets, serving in nursing homes, spreading photographs in public places to public spaces, and so forth.

According to sociologist Peter L. Berger (1990), social sanctions can be interpreted as a set of 
methods used by the community to curb dissident members.[40]. Meanwhile, Wignjosoebroto (2008) views social sanctions as a form of suffering that is deliberately given by the community.[41]. When referring to these two definitions, apart from the editors of different languages between the two, there is substantially a point of equality. The point of the equation is the emphasis on community participation. This then becomes the distinguishing aspect regarding the workings of social sanctions with positive law in general. If positive law is more oriented to the existence of official apparatus and institutions, then social sanctions are more complex because they also involve the participation of the community.

If explored further, social punishment or social sanctions are basically derived from the concept of social control terms. However, it should be noted, although it sounds different, but in its substance it has the same meaning, which is equally as having the vision to carry out prevention and enforcement of all forms of violations of the law. Whether it's social law or formal law. Roucek \& Warren, social control is a planned or unplanned process to teach individuals to be able to adjust to the habits and values of the groups in which they live.[42]. On another occasion, Soejono Soekanto in Setiadi et al (2011), defined social control as a process, whether planned or not, aimed at inviting, guiding or even forcing citizens to comply with applicable values and rules.

If related to the entire previous definition, textually the two definitions of Roucek-Warren and Soejono Soekanto look different. At Roucek and Warren, social control activities place more emphasis on the teaching aspect. That the process of social control over corrupt behavior must be carried out through educational activities. Educative itself is not merely focused on the role and function of school institutions, but must involve all elements of the educational institution. Whether it's education in the formal sector such as schools, or informal education such as family, community, and the like. According to Soejono Soekanto (2006), the process of social control must be carried out from all directions. Starting from a persuasive approach, even preventive ways.[43]. Control of deviant perpetrators (corruption) cannot be sufficient in the activities of guidance, teaching, and other forms of subtle approach as explained by Roucek and Warren, but at certain limits, social control must be maximized in a preventive form. This method is based on the fact that humans have free instincts (zoon politicon). Man's free instincts can only be conquered by enacting binding rules.

ndividual behavior is a self-objectification which is obtained through internalisation of values on one side, and externalization of values on the other side. Internalization is the process by which individuals absorb and imitate all the values, information and norms that surround them. at this stage it can be said that every what arises from him is a representation of the surrounding environment. The externalization is the stage where the individual expresses his subjective view into the praxis. So that it can be said that what arises from him, both in the form of attitudes, behaviors, and actions, all of which are manifestations of self subjectivity. Not as an environmental representation as happened in the internalization process. With this reading, corruption deviates as a form of objectivity in selfbehavior, at certain times it can occur due to subjective impulses (mentality), and can also be formed due to environmental (social) factors. In Peter L. Berger's language, behavioral objectification (corruption) based on the process of internalization and externalization is known as the social construction trialectika.[45].

If corruption deviant behavior is caused by a double impulse, between the results of self-understanding and external drive, then this can be interpreted that efforts to prevent and eradicate corrupt behavior cannot be focused on one door, but must include both. Whether it concerns issues at the subjective level or the whole system and social structure outside of himself. Some subjective problems referred to here are all psychological aspects related to mentality, self-awareness, and mindset. Handling 
in this sector can be carried out through dedicated activities. For example, providing anti-corruption education and introducing the latent dangers of corruption from an early age. The problems in the scope of the system and structure are such as weak rule of law, weak enforcement, and so forth. The strategic step to improve problems in this sector is through the optimization and strengthening of the pillars of law enforcement as a whole. Both in the police institutions, courts, and in institutions relating to corruption itself, KPK.

\section{Social Sanctions as an Instrument of Corruption Prevention and Enforcement}

According to Emile Durkheim (in SoerjonoSoekanto, 1985), the context of the prevention and enforcement of corruption, the application of social sanctions can be carried out through the involvement of social institutions collectively.[46] There are at least five important elements, namely; family, tradition, education, law enforcement, and religion.

\section{Family}

Horton and Hunt (1996) classify families as primary groups. Primary means principle, main, and basic. Because of this basic nature, the family as the absolute smallest social structure has a fundamental role and function in the midst of community life. Opponents of primary are secondary. If the primary is the principle, the secondary is another element that is based on the primary element.[47]. Exactly, when referring to Horton and Hunt's explanation above, the family is the foundation structure, where other elements outside it, such as religion, education, and law, are strongly influenced by the existence of the family. In this strategic position, the family has a strategic role and function in instilling the values of anticorruption education.

In the case of social control of corruptive behavior, the family is the first institution that has many functions. At the very least, there are three (3) main functions of the family in relation to eradicating corruption, namely; the function of forming, developing, and controlling at the same time. The function of the family as a maker (creator), refers to his role as the initial stage of character and personality building. At this stage, the family can be likened to a miniature school, in which the values of honesty, noble values, virtue values are instilled as often and as strongly as possible. The function of the family as a forum for development, presupposes other functions as a miniature school. Namely, self-sensitivity in reading all forms of potential that can strengthen identity and character, so as to increase the value of self-quality to be better and more perfect. Whereas the function of the family as a controller implies that the family must be able to perform a dual function, a disciplinary function as well as a punishment function. The disciplinary function plays a strategic role to build and form self-sufficiency that obeys rules and regulations. Whereas giving punishment, besides being an instrument gives a deterrent effect, it also teaches about the importance of responsibility, honesty.

\section{Tradition}

Etymologically, tradition has the meaning of rules (deeds and so on) which are commonly followed or carried out since time immemorial; ways (behavior and so on) that have become a habit; manifestation of cultural ideas consisting of cultural values, norms, laws, and rules that relate to one another into a system.[48]. Exactly, in a simpler sense, adat is a set of values, norms, rules, views of life that are local and in effect long ago. If it refers to this nature, then the idea of the enactment of social functions through an adat approach is another meaning of optimizing the eradication of corruption based on local wisdom values.

Theoretically, strengthening social sanctions through adat is actually not new in the discussion of positive law. Adat is an integral part of legal products, because that is where the starting point for informal legal instruments is produced and enforced. According to Friedman (2001), in 
principle, legal culture contains two things; 1) elements of organic customs that are related to culture as a whole, and; 2) elements of values and social attitudes regarding asbtrak and subjective views.[49]. If reflecting on this point, the position of adat as an element of legal culture means that considering the locality aspect in the application of law, including in terms of combating corruption, is an important aspect that needs attention. In addition, the fact that the formation of customs acquired down and down can be an effective model of social control, especially in terms of disciplining people who are still thick with traditional value systems. At some point, customary law has a normative level higher than written law. This is because the process of formation is based more on consensus, noble values, religious norms and morality. This is very different from the characteristics of positive law that emphasizes rationality.

\section{Law Enforcement}

The legal support pillars such as the court, prosecutors' office and the police have a fundamental function in the process of social control. The strength of these institutions lies in the strength and aspects of their legality in treating the law firmly, independently and thoroughly. Imposing a conviction or prosecution that truly gives a deterrent effect on the perpetrators of corruption, so that it can give fear to repeat the same actions in the future. In addition to giving fear to the perpetrators, it also serves to give warnings to others, so as not to get closer to corruption.

Unfortunately, with regard to prosecution and criminalization of corruption, it must be admitted that so far there are still a number of issues that have not been fully resolved properly. One of them is related to the legal verdict on convicted of corruption which is still not fully maximized, so that the deterrent effect is far from burning. This fact is reinforced by the Kompas Research and Development Survey (2013), where 89.9 percent of all respondents expressed dissatisfaction with the current criminal conviction situation.[50]. Therefore, with the reality of this weak prosecution and punishment, it is necessary to take courage to make improvements and strengthen justice aspects in all sectors. Both the system and the actors who run the law itself. In plain language, improvements at the level of law enforcement are not sufficiently based on the area of the system, but also on the mentality of the apparatus who carry out the law

\section{Education}

Education based on strengthening character has a big role in the process of social control, especially towards groups of people who are in the young age group. Nasution (2010) states that social control within an educational institution is centered on the function of the teacher.[51]. The teacher has an important role in the formation of the child's mentality. Be a wise person, honest, and uphold noble values and virtues. In this position, educational institutions must be able to play an active role in the school environment, introduce the dangers of corruption and provide knowledge to students about the importance of distancing themselves from all corrupt practices.

The thing that needs to be emphasized here is that the cultivation of anti-corruption values through educational activities is not only limited to the role and function of formal education institutions, such as school institutions. Anti-corruption education is a simultaneous action involving all elements of educators, and society as a whole. In this connection, all social institutions, both formal and non-formal, such as family organizations, traditional assemblies, learning communities, social activists, and all other elements, can become a strategic medium, where the value of anticorruption education is instilled in the whole community, especially children as the next generation of nations

\section{Religion}

Religion has advantages at the center of their teachings which uphold moral values, virtue, nobleness, and respect for humanism. In its position as a source of morality, religion strictly forbids its 
adherents to do all forms of evil, both those related to God and those related to others. In addition, with regard to the behavior of corruption, corruption as a form of abuse of authority, corruption as an act of deprivation of state wealth, and corruption as castration of people's rights, all of which constitute behavior contrary to religious teachings. In this connection, making religion as an instrument of corruption eradication implies the real effort to bring the values and teachings of religion into the consciousness of each individual, so that religion with all its moral value devices can function strategically to control its adherents to not apply impure.

Another thing that can be done with regard to the use of the function of religion as an instrument of corruption eradication, is by maximizing religious institutions and religious leaders. For example, encouraging all religious leaders to actively convey the prohibition of corruption, or can also by optimizing the role of certain religious institutions to affirm the ban on corruption, for example encouraging the Indonesian Ulema Council (MUI) in order to give a special fatwa on corrupt behavior. Sociologically, those efforts are important as a joint step to eradicate corruption collectively. Moreover, as understood together, borrowing the language of Michel Foucault, that the powerful means of producing power are religion, it cannot be separated from the mechanisms and techniques of normative and disciplinary power, able to produce identities that can facilitate obtaining compliance and obedience from its adherents.[52].

Therefore, if we refer to the explanations, it can be said that strengthening the eradication of corruption through the application of sanctions or social control, basically more on the overall utilization of the structure and institutions of society as a whole. Starting from the smallest structure such as a family, to the highest structure such as a government agency. Sociologically, the engagement of all elements and structures of society to participate in fighting corruption is a manifestation of their respective consensus, that every behavior of corruption is a form of deviation and violation of norms. Whether it's religious norms, social norms, cultural norms, and positive legal norms. Because of this consensus, the eradication of corruption must not run in one door, but must synergize through the other doors. In connection with this study, the imposition of sanctions or social laws against corruptors can be interpreted as a prevention and eradication strategy implemented through a collective approach and approach.

\section{CONCLUSION}

The problem of corruption in Indonesia has such complex problems that all have their roots in two factors at once, namely structural and cultural factors. In the structural dimension, corruption is more dominated by the roles and functions of certain institutions which are not optimal in terms of corruption prevention and enforcement. For example, as is the application of law for corruptors who are not yet oriented to providing a deterrent effect. In this connection, the application of a single law oriented to positive law needs to be strengthened through other instruments which can strengthen existing legal regulations or enforcement. Whereas in the cultural dimension of corruption occurs due to the factor of mentality of self relating to awareness, honesty, justice, all of which are rooted in the aspects of education and education. As a follow-up of the two factors above, namely structural and cultural factors, a special approach is needed so that the process of preventing and fighting corruption runs more optimally. The instrument referred to here is the idea of applying social punishment. Social punishment presupposes the application of participatory and open law which emphasizes the presence of society as a whole. at the level of theory and practice, the idea of preventing and prosecuting corruption through the imposition of social sanctions or sanctions involves five (5) structures, namely; 1) education structure that is based on anti-corruption education; 2) 
Family structure, family presence in instilling the values of virtue, honesty, fairness, and nobility; 3 ) Customary structure, i.e. how traditional or cultural systems are directed at building positive attitudes and behaviors, one of which is anti-corruption attitude; 4) Law enforcement, maximizing punishment for every corruptor as soon as possible; 5) Religious structure, maximizing the role and function of religious control as an instrument for identifying and instilling anti-corruption education.

\section{REFERENCES}

[1] Retnowati, Y., \& Utami, Y. S. (2014). Relevansi Gerakan Anti Korupsi Untuk Pembangunan. Paradigma, 18(1), 12-25.

[2] Joniarta, I. W. (2018). Banalitas Korupsi di Indonesia; Suatu Tinjauan Dari Perspektif Budaya. Jurnal Ilmiah Dinamika Sosial, 2(1), 142-159.

[3] Hasan, N. (2020). Corak Budaya Birokrasi Pada Masa Kerajaan, Kolonial Belanda Hingga Di Era Desentralisasi Dalam Pelayanan Publik. Jurnal Hukum, 28(2), 1073-1087.

[4] Wijayanto, R. Z. (2009). Korupsi Mengorupsi Indonesia. Jakarta: Gramedia Pustaka Utama.

[5] Syuraida, H. (2015). Perkembangan Pemberantasan Korupsi di Indonesia Era Orde Lama Hingga Hera Reformasi. Avatara, 3(2), 222-237.

[6] Suwirta, A. (2018). Pers dan Kritik Sosial pada Masa Orde Baru: Studi Kasus Pers Mingguan Mahasiswa Indonesia di Bandung, 1966-1974. Mimbar Pendidikan,3(2), 113136.

[7] Ermansyah, D. (2008). Memberantas Korupsi Bersama KPK. Jakarta: Sinar Grafika.

[8] Marta, F. (2019). Indeks Persepsi Korupsi RI Membaik, tetapi Korupsi Politik Dinilai Masih Tinggi, https://kompas.id/baca/utama/2019/01/29/ind eks-persepsi-korupsi-ri-membaik-namunkorupsi-politik-dinilai-masih-tinggi/.

[9] Kompas, "Pekerjaan Rumah Masih Menumpuk", https://kompas.id/baca/utama/2020/01/24/pek erjaan-rumah-masih-menumpuk/.
[10] Zuber, A. (2018). Strategi Anti Korupsi Melalui Pendekatan Pendidikan Formal dan KPK (Komisi Pemberantasan Korupsi). Journal of Development and Social Change, 1(2), 178-190.

[11] Girsang, J. (2012). Penyalahgunaan Kekuasaan Aparat Penegak Hukum dalam Penanganan Tindak Pidana Korupsi. Jakarta: JG Publishing.

[12] Apriani, L. R. (2010). Penerapan Filsafat Pemidanaan Dalam Tindak Pidana Korupsi. Jurnal Yudisial, 3(1), 1-14.

[13] Asnawi, H. S. (2013). Membongkar Paradigma Positivisme Hukum dalam Pemberantasan Korupsi di Indonesia: Pemenuhan Hak Asasi Manusia dalam Negara Hukum. Supremasi Hukum: Jurnal Ilmu Hukum, 2(2).

[14] Isra, S. (2011). Hukum Alat Rekayasa untuk Korupsi. Jakarta: Kompas.

[15] Prasetyo, A. Y. (2012). "Saatnya Hukuman Sosial bagi Para Koruptor," https://nasional.kompas.com/read/2012/10/22 /08253486/saatnya.hukuman.sosial.bagi.para. koruptor?page=all.

[16] Moqoddas, B. (2011). Strategi Pemberantasan Korupsi KPK. Jakarta: Kompas.

[17] Alim, H. (2016). Sanksi Sosial untuk Koruptor, https://mediaindonesia.com/read/detail/69503 -sanksi-sosial-untuk-koruptor.

[18] WIrartha, I. M. (2006). Metodologi Penetilian Sosial Ekonomi. Yogyakarta: Andi Offset.

[19] Sugiyono. (2010). Metode Penelitian Kuantitatif dan Kualitatif dan $R \& D$. Bandung: Alfabeta.

[20] Wijayanto, R. Z. (2009). Korupsi Mengorupsi Indonesia. Jakarta: Gramedia Pustaka Utama.

[21] Moqoddas, B. (2011). Strategi Pemberantasan Korupsi KPK. Jakarta: Kompas.

[22] Langseth, P., Stapenhurst, R., \& Pope, J. (1997). The role of a national integrity system in fighting corruption. Commonwealth Law Bulletin, 23(1-2), 499-528.

[23] Haryatmoko, J. (2010). Dominasi penuh muslihat: akar kekerasan dan diskriminasi. PT Gramedia Pustaka Utama.

[24] Rose-Ackerman, S., \& Palifka, B. J. (2016). Corruption and government: Causes, 
consequences, and reform. Cambridge university press.

[25] Heidenheimer, A. J., \& Johnston, M. (Eds.). (2011). Political corruption: Concepts and contexts (Vol. 1). Transaction Publishers.

[26] Adian, D. G. (2002). Percik Pemikiran Kontemporer. Yogyakarta: Jalasutra.

[27] Badudu, J. S. (2001). Kamus Besar Bahasa Indonesia. Jakarta: Balai Pustaka.

[28] Santoso, L., Meyriswati, D., \& Alfian, I. N. (2014). Korupsi dan mentalitas: kendala kultural dalam pemberantasan korupsi di Indonesia. Masyarakat, Kebudayaan dan Politik, 27(4), 173-183.

[29] Moqoddas, B. (2011). Strategi Pemberantasan Korupsi KPK. Jakarta: Kompas.

[30] Wijayanto, R. Z. (2009). Korupsi Mengorupsi Indonesia. Jakarta: Gramedia Pustaka Utama.

[31] Wijayanto, R. Z. (2009). Korupsi Mengorupsi Indonesia. Jakarta: Gramedia Pustaka Utama.

[32] Wijayanto, R. Z. (2009). Korupsi Mengorupsi Indonesia. Jakarta: Gramedia Pustaka Utama.

[33] Koenjataraningrat. (1987). Sejarah Teori Antropologi I. Jakarta: UI Press: Jakarta.

[34] Soekanto, S. (1985). Sosiologi Suatu Pengantar. Jakarta: Rajawali Pers.

[35] Ritzer, G. (2010). Teori Sosiologi Dari Klasik Sampai Postmodern. Bantul: Kreasi Wacana.

[36] Susanti, I. (2015). Perilaku Menyimpang Dikalangan Remaja pada Masyarakat Karangmojo Plandaan Jombang. Jurnal Paradigma, 3(2), 189-205.

[37] Susanti, I. (2015). Perilaku Menyimpang Dikalangan Remaja pada Masyarakat Karangmojo Plandaan Jombang. Jurnal Paradigma, 3(2), 189-205.

[38] Badudu, J. S. (2001). Kamus Besar Bahasa Indonesia. Jakarta: Balai Pustaka.

[39] Septiano, M. F. (2008). Pidana Kerja Sosial sebagai Alternatif Pidana Penjara Jangka Pendek. Malang: Universitas Brawjaya.

[40] Berger, P. L., \& Luckman, T. (1990). Tafsir Sosial atas Kenyataan. Jakarta: LP3ES.

[41] Wignjosoebroto, S. (2008). Hukum dalam Masyarakat, Perkembangan dan Masalah, Sebuah Pengantar ke Arah Sosiologi Hukum. Malang: Penerbit Bayu Publishing.

[42] Roucek, S. J., \& Warren, L. R. (1987). Pengantar Sosiologi. Jakarta: Bina Aksara.
[43] Soekanto, S. (1985). Sosiologi Suatu Pengantar. Jakarta: Rajawali Pers.

[44] Berger, P. L., \& Luckman, T. (1990). Tafsir Sosial atas Kenyataan. Jakarta: LP3ES.

[45] Berger, P. L., \& Luckman, T. (1990). Tafsir Sosial atas Kenyataan. Jakarta: LP3ES.

[46] Soekanto, S. (1985). Sosiologi Suatu Pengantar. Jakarta: Rajawali Pers.

[47] Horton, P. B., \& Hunt, C. L. (1996). Sosiologi. Jakarta: Grafindo.

[48] Badudu, J. S. (2001). Kamus Besar Bahasa Indonesia. Jakarta: Balai Pustaka.

[49] Friedman, L. M. (2001). American law, an Introduction. Jakarta: Tata Nisa.

[50] Kompas. Dari 4,5 Tahun, MA Perberat Vonis Angie Jadi $12 \quad$ Tahun. http://nasional.kompas.com/Dari.4.5.Tahun. MA.Perberat.

[51] Asren, N. (2012). Membangun Karakter Bangsa. Jakarta: Prenada.

[52] Haryatmoko, J. (2010). Dominasi penuh muslihat: akar kekerasan dan diskriminasi. PT Gramedia Pustaka Utama. 